\title{
Development of Three Row Animal Drawn Multi Crop Planter Cum Herbicide Applicator
}

\author{
S. Bisen, V. M. Victor* and A. K. Chandraker \\ Department of Farm Machinery \& Power Engineering, SV College of Agriculture \\ Engineering \& Technology \& Research Station, Indira Gandhi Krishi Vishwavidyalaya, \\ Raipur, Chhattisgarh, India \\ *Corresponding author
}

\section{A B S T R A C T}

\section{Keywords}

Multi crop planter, Draught animal, Sprayer, Herbicide applicator, Animal drawn implement

\section{Article Info}

Accepted:

12 December 2020 Available Online: 10 January 2021
Farm mechanization is a process which helps in increasing the production by timely farm operation, reducing losses and reducing the cost of operations. Man power and animal power are the major sources of farm power for small and marginal farmers in India. In this study an implement was developed to perform the operations of planting of seeds and application of herbicide simultaneously in order to aid small and marginal farmers to save money and time. It consists of a main frame, seed hoppers, seed metering devices, seed delivery tubes, inverted ' $\mathrm{T}$ ' type furrow openers, sprayers, boom, nozzles, ground wheel, ground wheel lifting mechanism and handle. The developed implement was fabricated with the materials which are available locally at cheap cost. Fabrication cost of the implement was kept at minimum. The average field capacity and mean field efficiency was $0.121 \mathrm{ha} / \mathrm{h}$ and 70.70 per cent respectively. The average discharge of boom was 965.2 $\mathrm{ml} / \mathrm{min}$ at an average pressure of $254.97 \mathrm{kPa}$. The average cost of operation was determined as Rs. 650 per ha.

\section{Introduction}

Sustainable development can be achieved by use of mechanization in agriculture. Farm mechanization helps in increasing the production by timely farm operation, reducing losses and reducing the cost of operations. It should benefit all the farmers irrespective of the size of their land holdings. Farm mechanization is primarily focused on farmers with medium and large size land holdings as they are benefitted with different types of agricultural machines which are inoperable and uneconomical to farmers with small and marginal land holdings. In India, small and marginal land holdings constitute a large portion of total land holdings. Agricultural productivity depends on availability of farm power sources. Main farm power sources for small and marginal farmers are man power and animal power. Animal power is provided by draught animals and is called as draught animal power. Design and development of farm implements are carried are considering these sources of power for small and marginal farmers. 
A study was conducted by Kawade et al., in which a three row multi crop bullock drawn planter was tested and the field capacity of the planter was found to be 2 ha/day with an average field efficiency of 75 per cent. The planter saved 9-27 per cent seed and 63-75 per cent labour work. A single row tillage cum multi crop planter was developed by Abebe (2018) mainly for sorghum and maize crops and strip tillage practice. Field efficiencies of planter was found out to be 77.47 per cent for maize trail and 76.52 per cent for sorghum trail. Dhruwe et al., (2018) developed a five row animal drawn multi crop planter and its performance was evaluated through lab tests and field trials. The mean field capacity was $0.22 \mathrm{ha} / \mathrm{h}$ with 79.78 per cent field efficiency. Ghosal and Pradhan (2012) modified the design of cups in cup feed metering seed drill for seed pattern characteristics study of black gram seeds. Dimensions of cup i.e. $6 \mathrm{~mm}$ x $2.89 \mathrm{~mm}$ was found to be best and was used successfully up to a peripheral speed of $18.84 \mathrm{~m} / \mathrm{min}$. Overall efficiency was found to be 79.94 per cent. They conducted a similar study for green gram and the filed efficiency of seed drill was found to be 78.75 per cent (Ghosal and Pradhan, 2013).

A study conducted by Verma et al., (2007) tested and compared shoe type furrow opener, shove type furrow opener and inverted ' $\mathrm{T}$ ' type furrow opener on the basis of draft requirement, soil disturbance and seed emergence. The lowest draft of $32.12 \mathrm{kgf}$ was required by inverted ' $\mathrm{T}$ ' type furrow opener. Waghmare (2017) developed a bullock drawn multipurpose tool carrier for sowing, fertilizer application and herbicide application simultaneously. Draft requirement was $62 \mathrm{~kg}$ and average discharge of boom was 783.95 $\mathrm{ml} / \mathrm{min}$ at $2.10 \mathrm{~kg} / \mathrm{cm}^{2}$ pressure.

A machine that performs multiple operations at the same time and which can be used for different crops saves time, money and labour. Planting and plant protection are some of the most important agricultural operations. A three row animal drawn multi crop planter cum herbicide applicator fulfills the requirement of performing two different operations i.e. planting and herbicide application simultaneously.

\section{Materials and Methods}

This study was conducted in the year 2018 at Department of Farm Machinery and Power Engineering, Swami Vivekananda College of Agricultural Engineering \& Technology and Research Station, IGKV, Raipur. The main components are frame, furrow opener, ground wheel, power transmission system, hopper, seed metering mechanism, seed delivery tubes, hitching system, hand and beam, sprayer, sprayer boom and sprayer nozzles.

\section{Main frame}

A square shaped pipe of mild steel of size 50 x $50 \times 5 \mathrm{~mm}$ was used for the frame. The length of the frame was kept $1675 \mathrm{~mm}$ in order to accommodate 3 furrow openers with the recommended spacing of crops to be cultivated and to have a desirable turning radius along with two sprayers placed on the either ends.

\section{Furrow openers}

Three inverted ' $\mathrm{T}$ ' type furrow openers were developed. MS flat of $100 \times 95 \mathrm{~mm}$ was drilled with four holes and welded to the tyne for clamping purpose. The total height of tyne of furrow opener was $497 \mathrm{~mm}$ and width was $290 \mathrm{~mm}$. An extension was provided on the top of the furrow opener with two holes to mount the hopper with the help of nuts and bolts and could be adjusted to obtain desired furrow spacing as per crop requirements. Point of share was made of carbon steel with 
carbon content of 0.5 per cent and thickness of $10 \mathrm{~mm}$. The tyne was made of mild steel flat of width $40 \mathrm{~mm}$ and thickness $10 \mathrm{~mm}$

\section{Ground wheel}

A ground wheel of diameter $470 \mathrm{~mm}$ was constructed by using $25 \times 4 \mathrm{~mm}$ MS flat of 117 $\mathrm{cm}$ and bending it to a circle. 10 pegs of 50 mm length were made of same material and welded at uniform distances. The diameter of $470 \mathrm{~mm}$ was selected for the ground wheel considering the speed of operation as 1.75 $\mathrm{km} / \mathrm{h}$

\section{Power transmission system}

The power transmission system was designed to provide power to the seed metering devices and crank mechanism for sprayers from the ground wheel. Chain and sprockets were used for the power transmission system. Provisions were made so that the sprockets can be changed easily to change the speed ratio for achieving different seed rates for different crops. Power from ground wheel was transmitted to main shaft through an intermediate shaft.

Main shaft simultaneously powered both seed metering mechanism and inline slider crank mechanism which operated the sprayer pistons. With the speed of ground wheel of $19.75 \mathrm{rpm}$ speed ratio of 2.03 the speeds of shaft driving seed metering mechanism was obtained as $39.7 \mathrm{rpm}$ and for the inline slider crank mechanism, speed of the shaft was $25.28 \mathrm{rpm}$ with 1.28 speed ratio.

\section{Hopper}

Seed hopper consisted of seed box, circular plate with cells, metering shaft and seed tube mounting pipe. A readymade hopper made of PVC with angle of repose of $30.95^{\circ}$ was used.

\section{Seed metering mechanism}

Cell feed metering mechanism was used to meter the seeds. The rate of seed delivery depends upon the size and number of cells or hubs present in the rotor and the speed ratio of metering shaft and ground wheel shaft. Readymade standard vertical cell rotors of 5 different types were tested to meter the selected seeds. These rotors were design for specific crop as different crops have different seed density, seed spacing, shapes and size.

\section{Seed delivery tube}

PVC tube of $46.5 \mathrm{~mm}$ outer diameter and 280 $\mathrm{mm}$ length were used for passing of seeds from the seed metering devices to the boot of the furrow opener.

\section{Hitching system}

The hitch was made up of two mild steel flat of $350 \times 40 \mathrm{~mm}$ with a distance of $70 \mathrm{~mm}$ inbetween the flats. It was fabricated by taking two MS flats of length $350 \mathrm{~mm}$ on which a flat of length $125 \mathrm{~mm}$ was welded at an angle $68^{\circ}$ at front end and at the rear end it was welded to the frame. Holes of $10 \mathrm{~mm}$ were drilled at different position in the hitch to facilitate the adjustment of beam height. A beam was used to attach hitch of the implement to the yoke.

\section{Handle}

The handle was provided in the implement to control and maneuver the developed implement easily during operation. The handle was made up of MS square pipe of $25 \mathrm{~mm}$ sides. It was made by welding three different lengths $(130 \mathrm{~mm}, 380 \mathrm{~mm}$ and $55 \mathrm{~mm}$ ) of MS square together at a suitable angle forming a single unit. The height of handle was decided considering the ergonomic aspect of the operator. 


\section{Sprayer}

Lever operated knapsack sprayers of 16 liters capacity were used. The sprayers were dismantled and the function of lever was replaced by crank mechanism to operate the sprayers.

\section{Sprayer boom}

Sprayer boom was made of 4 hose pipes of standard size which are available easily in the market. These hose pipes were connected with $3 \mathrm{~T}$ pipe joints in such a way that the 2 ends of the $\mathrm{T}$ pipe joints were connected to the hose pipes and the bottom end was fitted with sprayer nozzle. The either ends of the boom were connected to the piston of both sprayers.

\section{Sprayer nozzle}

Flat fan type nozzles made of PVC were used as per the spraying requirements. The use of other types of nozzles was not practical with the present planter cum sprayer.

\section{Performance evaluation}

The developed machine was tested in laboratory and in field as per the standard procedure by using IS 6316: 1993 and IS 10134: 1994 test codes. The developed implement was evaluated on the basis of parameters such as seed rate, nozzle discharge rate, pressure developed in sprayer boom, speed of operation, field capacity, field efficiency, draft requirement, power requirement and cost of operation. The implement was tested and evaluated for seeding of maize under controlled lab conditions. Field tests were carried out in an area of $21 \times 19 \mathrm{~m}^{2}$. The different component of the three row multi crop planter cum herbicide applicator were fabricated and assembled in the college workshop. The specifications of the developed implement are depicted systematically in Table 1 and isometric view of developed machine is shown in Fig. 1.

\section{Results and Discussion}

The developed sprayer cum planter was tested in the research field of SVCAET\&RS, IGKV Raipur (C.G.). Missing and multiple indices were calculated for the seed spacing of 150 $\mathrm{mm}$ for maize crop. Missing index and multiple index was found 10.2 per cent 11.8 per cent respectively (Table 4). The pressure was recorded from the pressure gauge at five different instances. The average pressure value recorded was $254.97 \mathrm{kPa}$ (Table 3).

The obtained seed rate during laboratory test was found $42.86 \mathrm{~kg} / \mathrm{ha}$ for maize which was closer to the recommended seed rate. Mechanical damage to the seeds by metering mechanism was recorded through visual observation. The damage percentage of seeds was found 0.64 per cent. The damage percentage was less than $1 \%$ significance for selected crop.

Discharge rate from three flat fan nozzles was measured in $\mathrm{ml} / \mathrm{min}$ at the pressure 254.97 $\mathrm{kPa}$. The discharge rates were found out to be $321.8 \mathrm{ml} / \mathrm{min}, \quad 313.8 \mathrm{ml} / \mathrm{min}$ and 329.6 $\mathrm{ml} / \mathrm{min}$ for nozzles $\mathrm{N}_{1}, \mathrm{~N}_{2}$ and $\mathrm{N}_{3}$ respectively (Table 2). The total discharge rate of boom was $965.2 \mathrm{ml} / \mathrm{min}$.

Machine performance results of developed machine are presented in Table 4. The average draft of the implement was found out to be $443 \mathrm{~N}$. The actual field capacity was found out to be $0.121 \mathrm{ha} / \mathrm{h}$. Time required to cover 1 ha area was observed as $8.26 \mathrm{~h} / \mathrm{ha}$. Herbicide application was also carried out simultaneously. Field efficiency of the machine was determined as $70.7 \%$. 
Table.1 Specification of a three row animal drawn multi crop planter cum herbicide applicator

\begin{tabular}{|c|c|c|}
\hline S. $\mathbf{N}$. & Particulars & Specifications \\
\hline 1. & Name & $\begin{array}{l}\text { Three row animal drawn multi crop } \\
\text { planter cum herbicide applicator }\end{array}$ \\
\hline 2. & Size (length $\mathrm{x}$ breadth $\mathrm{x}$ height) & $1710 \mathrm{~mm} \times 1070 \mathrm{~mm} \times 1160 \mathrm{~mm}$ \\
\hline 3. & Depth of sowing $(\mathrm{mm})$ & Adjustable \\
\hline 4. & Row to row spacing (mm) & $225,300,400$ and 450 \\
\hline 5. & Working width $(\mathrm{mm})$ & 1350 \\
\hline 6. & Furrow opener & Inverted ' $\mathrm{T}$ ' type \\
\hline 7. & No. of furrow openers & 3 \\
\hline 8. & Type of metering device & Cell feed metering device \\
\hline 9. & Ground wheel diameter (mm) & 470 \\
\hline 10. & No. of nozzles & 3 \\
\hline 11. & Average boom pressure, $\mathrm{kPa}$ & 254.97 \\
\hline 12. & Nozzle spacing, $\mathrm{mm}$ & 225 to 450 \\
\hline 13. & Nozzle height, mm & 350 to 550 \\
\hline 14. & Spray angle, ${ }^{\circ}$ & 60 \\
\hline 15. & Power transmission & $\begin{array}{l}\text { Chain and sprocket system, inline } \\
\text { slider crank mechanism }\end{array}$ \\
\hline 16. & Source of power & Pair of draught animal \\
\hline 17. & Weight (kg) & 70 \\
\hline 18. & Labour requirement & 1 \\
\hline
\end{tabular}

Table.2 Discharge rate of nozzles

\begin{tabular}{|l|c|c|c|c|}
\hline \multirow{2}{*}{ Trial } & \multicolumn{3}{|c|}{ Nozzle discharge rate, ml/min } & Discharge rate of \\
\cline { 2 - 5 } & $\mathbf{N}_{\mathbf{1}}$ & $\mathbf{N}_{\mathbf{2}}$ & $\mathbf{N}_{\mathbf{3}}$ & $\begin{array}{c}\text { spayer boom, } \\
\text { ml/min }\end{array}$ \\
\hline $\mathbf{1}$ & 314 & 304 & 322 & 940 \\
\hline $\mathbf{2}$ & 319 & 306 & 327 & 952 \\
\hline $\mathbf{3}$ & 322 & 315 & 331 & 968 \\
\hline $\mathbf{4}$ & 325 & 319 & 332 & 986 \\
\hline $\mathbf{5}$ & 329 & 325 & 336 & 990 \\
\hline Average & 321.8 & 313.8 & 329.6 & 965.2 \\
\hline
\end{tabular}

Table.3 Test results of sprayer related parameters

\begin{tabular}{|l|c|}
\hline \multicolumn{1}{|c|}{ Particular } & Observation \\
\hline Average pressure developed in boom, kPa $^{\circ}$ & 254.97 \\
\hline Spray angle, $^{\circ}$ & 60 \\
\hline Average discharge of boom, $\mathbf{~ m l / m i n}$ & 965.2 \\
\hline
\end{tabular}


Table.4 Machine performance result of developed multicrop planter cum applicator

\begin{tabular}{|l|l|c|}
\hline S. N. & Parameters & Result \\
\hline $\mathbf{1 .}$ & Missing Index, \% & 10.2 \\
\hline $\mathbf{2 .}$ & Multiple Index, \% & 11.8 \\
\hline $\mathbf{3 .}$ & Depth of operation, $\mathrm{mm}$ & 44.67 \\
\hline $\mathbf{4 .}$ & Pressure in boom, $\mathrm{kg} / \mathrm{cm}^{2}$ & 2.6 \\
\hline $\mathbf{5 .}$ & Speed of operation. $\mathrm{Km} / \mathrm{h}$ & 1.82 \\
\hline $\mathbf{6 .}$ & Draught, N & 444 \\
\hline $\mathbf{7 .}$ & Power output, $\mathrm{kW}$ & 0.22 \\
\hline $\mathbf{8 .}$ & Theoretical field capacity, ha/h & 0.171 \\
\hline $\mathbf{9 .}$ & Actual field capacity, ha/h & 0.121 \\
\hline $\mathbf{1 0}$. & Time required to cover $1 \mathrm{ha}, \mathrm{h} / \mathrm{ha}$ & 8.26 \\
\hline $\mathbf{1 1}$. & Field efficiency, $\%$ & 70.70 \\
\hline $\mathbf{1 2}$. & Cost of operation, $\mathrm{Rs} . / \mathrm{ha}$ & 650 \\
\hline $\mathbf{1 3}$. & Operational energy, $\mathrm{MJ} / \mathrm{ha}$ & 117.81 \\
\hline
\end{tabular}

Fig.1 Isometric view of developed three row animal drawn multi crop planter cum herbicide applicator

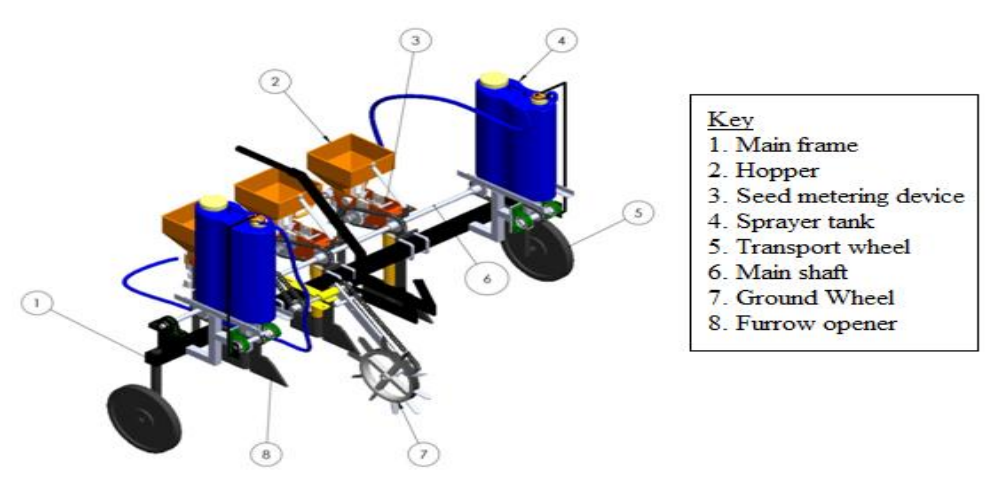

The estimated cost of implement including material cost and fabrication cost was estimated as Rs. 15000. The cost of sowing operation per hectare was calculated Rs. 650/ha for seeding maize crop with developed machine. Operational energy of the developed machine was determined as $117.81 \mathrm{MJ} /$ ha for seeding operation of maize.

In conclusion the three row animal drawn multi crop planter was designed and fabricated with the materials which are available locally at cheap cost. The machine developed was light in weight. The developed implement was subjected to laboratory tests and field tests and its performance was found to be satisfactory. The developed implement was rigid and sturdy and performed the operations of planting and herbicide application simultaneously without any issue. The average draft requirement was within the pulling capacity of medium size bullocks of this region. The average seed rates obtained were close to the recommended seed rates.

\section{Acknowledgement}

Authors are highly grateful to officials of All 
India Coordinated Research Project on Utilization of Animal Energy funded by ICAR New Delhi for providing necessary facility to conduct this study.

\section{References}

Abebe, F. (2018). Development and evaluation of animal drawn, single row tillage cum multicrop planter. Academic Research Journal of Agricultural Science and Research, 6(8): 500-508.

Dhruwe, N.K., Victor, V.M., Namdeo, A. and Nishad, P.K. (2018). Performance evaluation of five row animal drawn multi crop planter. International Journal of Current Microbiology and Applied Science, 7(2): 1547-1551.

Ghosal, M.K. and Pradhan, S.C. (2012). Design modifications of cup in cup feed metering seed drill for seed pattern characteristics study of black gram seeds. Engg. and Tech. in India, 3(2): 77-82.

Ghosal, M.K. and Pradhan, S.C. (2013). Performance study of a low cost manually operated cup feed metering seed drill for sowing green gram.
Agricultural Engineering Today, 37(1): 37-41.

IS 10134:1994. Methods of tests for manually operated sprayers. Bureau of Indian Standards, New Delhi.

IS 6316:1993. Test code for seed cum fertilizer drill. Bureau of Indian Standards, New Delhi.

Kawade, S.C., Srinivas, Indavarapu, Adake, R.V., Digrase, S.S., Dattatri, K., Sudhakar, N. and Mayande, V.M. (2015). Farmer participatory refinements and adoption of CRIDA bullock drawn planter in Latur district of Maharashtra. Indian Journal of Dryland Agricultural Research and Development, 30(2): 93-99.

Verma A.K. and Dewangan M.L. (2007). Mechanical consideration for design and development of furrow openers for seed cum fertilizer drill. Agricultural Mechanization in Asia, Africa and Latin America, 38(2): 30-34.

Waghmare, A. A. (2017). Design and development of bullock drawn multi purpose tool carrier. Unpublished M. Tech Thesis submitted to Vasantrao Naik Marathwada Krishi Vidyapeeth, Parbhani.

\section{How to cite this article:}

Bisen, S., V. M. Victor and Chandraker, A. K. 2021. Development of Three Row Animal Drawn Multi Crop Planter Cum Herbicide Applicator. Int.J.Curr.Microbiol.App.Sci. 10(01): 951-957. doi: https://doi.org/10.20546/ijcmas.2021.1001.115 